\title{
Isolation and Screening of Potassium and Zinc Solubilizing Bacteria from Different Rhizosphere Soil
}

\author{
Bhagwan Singh Dhaked", S. Triveni, R. Subhash Reddy and G. Padmaja \\ Department of Agricultural Microbiology and Bioenergy, College of Agriculture, Professor \\ Jayashankar Telangana State Agricultural University, Rajendranagar, Hyderabad-500030, India \\ *Corresponding author
}

\begin{abstract}
A B S T R A C T
Interaction between soil microbes and minerals play a major role in environmental cycling processes, which leads to the mobilization of nutrients from soil components into available forms for biological uptake which enhances crop growth and yield. In the present study four (4) potassium solubilizing bacteria (KSB), eight (8) zinc solubilizing bacteria ( $\mathrm{ZnSB})$

Keywords

Potassium and zinc solubilizing bacteria.

Article Info

Accepted:

17 June 2017 Available Online: 10 August 2017 and two (2) zinc solubilizing fungi ( $\mathrm{ZnSF}$ ) isolated from Rice, Maize, Cotton and Sorghum rhizosphere soil collected from Student and College farm Rajendranagar PJTSAU Hyderabad. The isolated KSB isolates screened for solubilization of insoluble potassium source (potassium alumino silicate) and zinc oxide $(\mathrm{ZnO})$. The solubilization zone for potassium is ranged from $160 \mathrm{~mm}$ to $85 \mathrm{~mm}$. The isolate KSB-2 showed maximum solubilization zone of $160 \mathrm{~mm}$. The solubilization efficiency (\%) ranges from 212.50 to $150 \%$ which was maximum for KSB-3 (212.50\%). The solubilization zone is ranged from $16 \mathrm{~mm}$ to $6 \mathrm{~mm}$ for zinc oxide $(\mathrm{ZnO})$. The isolate $\mathrm{ZnSB}-3$ showed maximum solubilization zone of $16 \mathrm{~mm}$. The solubilization efficiency (\%) ranges from 333.33 to 150 $\%$ which is maximum for ZnSB-1 (333.33\%). The isolate ZnSF-1 showed maximum solubilization zone of $85 \mathrm{~mm}$ followed by $\mathrm{ZnSF}-2$ with $34 \mathrm{~mm}$ for $\mathrm{ZnO}$. The solubilization zone is ranged from $6 \mathrm{~mm}$ to $25 \mathrm{~mm}$ for $\mathrm{ZnP}$. The isolate $\mathrm{ZnSB}-8$ showed maximum solubilization zone of $25 \mathrm{~mm}$ for zinc phosphate. The solubilization efficiency (\%) ranges from 157.14 to $500 \%$ which was maximum for $\mathrm{ZnSB}-8(500.0 \%)$ and least for $\mathrm{ZnSB}-6$ $(157.14 \%)$.
\end{abstract}

\section{Introduction}

Plant nutrition is the study of the mineral elements that are necessary for good plant growth and reproduction. Plant nutrition is closely associated with the activity of plant growth promoting rhizobacteria (PGPR), including potassium and zinc solubilizing bacteria (KSB and $\mathrm{ZnSB}$ ) which are used, as bio fertilizer in many countries that where in soil are deficient in available potassium and zinc. In soils, $\mathrm{K}$ occurs in the form of silicate minerals viz., muscovite, orthoclase, biotite, feldspar, illite, mica, vermiculite, smectite etc. Total pool of soil $\mathrm{K}$ is extremely complex and this can be solubilized by bacteria through production of acids and it will be available for plant (Ullaman et al., 1996). The use of plant growth promoting rhizobacter (PGPR), including potassium solubilizing bacteria (KSB) as biofertilizers, was suggested as a sustainable solution to improve plant nutrition and production (Badar et al., 2006). 
Zinc-solubilizing microorganisms can solubilize zinc from inorganic and organic pools of total soil zinc and can be utilized to increase zinc availability to plants. Fungi have been extensively studied for solubilization of insoluble zinc compounds both in vitro and in vivo. However, only some bacterial species of the genera Acinetobacter, Bacillus, Gluconacetobacter, and Pseudomonas have been reported (Gadd, 2007).

Bacteria are known to immobilize metal by precipitation and adsorption. The ability to dissolve immobilized zinc viz. zinc phosphate, zinc oxide and zinc carbonate in appreciable quantity is not common feature amongst the cultivable bacteria. Few Zn solubilizing bacterial genera viz., Thiobacillus thioxidans, Thiobacillus ferroxidans, Acinetobacter, Bacillus, Gluconacetobacter, Pseudomonas and facultative thermophilic iron oxidizers have been reported as zinc solubilizers (Saravanan et al., 2007)

\section{Materials and Methods}

The present investigation was carried out at the Department of Agricultural Microbiology and Bioenergy, College of Agriculture, Rajendranagar, Hyderabad for isolation and characterization of potassium and zinc solubilizing bacteria from different rhizosphere soil.

The general laboratory techniques followed in the present study were those described by Cappuccino and Sherman (1992), Nene and Thapliyal (1993) and Aneja (2001) for preparation of media, sterilization, isolation and maintenance of bacterial cultures, with slight modifications wherever necessary.

\section{Collection of rhizosphere soil}

Rhizosphere soils of different crop plants like maize, rice, cotton, sorghum were collected from College farm and Student farm, College of Agriculture, Rajendranagar, Hyderabad (Table 1).

\section{Isolation of rhizobacterial strains from different rhizosphere soil}

Rhizosphere soils of different crop plants are collected from college farm and student farm for isolation of rhizosphere bacteria by serial dilution plate method. Purification was done by streak plate method

\section{Isolation of potassium solubilizing bacteria (KSB)}

The potassium solubilizing bacteria were isolated from the rhizosphere soil by serial dilution plate method using modified Aleksandrov medium containing $0.2 \%$ insoluble mica powder or potassium alumino silicate as insoluble potassium source. The serial dilutions of the soil samples were made up to $10-5$ and $0.1 \mathrm{ml}$ of diluted soil suspension was plated on Aleksandrov medium plates. The plates were incubated at $28 \pm 2{ }^{\circ} \mathrm{C}$ in biological oxygen demand (BOD) incubator for 3-4 days. Detection of potassium solubilization by different rhizobacterial isolates was based upon the ability of solubilization zone formation. The rhizobacterial strains/isolates were maintained by transfer on Aleksandrov agar medium slants. These bacterial cultures were stored at $4^{\circ} \mathrm{C}$ in refrigerator for further use.

\section{Isolation of zinc solubilizing bacteria (ZnSB)}

Isolation of zinc solubilizing bacteria from the rhizosphere by soil serial dilution plate method on mineral salts agar medium was amended with $0.1 \%$ of either insoluble zinc oxide $(\mathrm{ZnO})$ or zinc phosphate. The serial dilutions of the soil samples were made up to $10-5$ and $0.1 \mathrm{ml}$ of diluted soil suspension was plated on mineral salts agar medium plates. 
The plates were incubated at $28 \pm 2{ }^{\circ} \mathrm{C}$ incubator for 3-4 days. Detection of zinc solubilization by different rhizobacterial isolates were based upon the ability of solubilization zone formation. The rhizobacterial strains/isolates were maintained by transferring on mineral salts agar medium slants. These bacterial cultures were stored at $4^{\circ} \mathrm{C}$ in refrigerator for further use. 2. Screening of bacterial isolates

To screen pure isolates from different rhizosphere soil for potassium and zinc solubilization

Pure isolates were obtained by streak plate method on different media will be screened for potassium and zinc solubilization by plate assay. Screening of Rhizobacterial Isolates for Formation of K- Solubilization Zone Potassium solubilization by rhizobacterial isolates were studied on modified Aleksandrov medium plates by the spot test method. Plates of modified Aleksandrov medium having potassium alumino silicate (insoluble form of potassium) were prepared. A loopful of $48 \mathrm{~h}$ old growth of the rhizobacterial strain $(10 \mu \mathrm{L}$ of $106 \mathrm{cfu} / \mathrm{ml})$ was spotted on above prepared plates. Four bacterial cultures were spotted on each plate. Plates were incubated at $28 \pm 2^{\circ} \mathrm{C}$ for 3 days. Detection of potassium solubilization by different rhizobacterial isolates were based upon the ability of solubilization zone formation. The diameter of colony and clear zone around the colony were measured for calculating the solubilization efficiency in percent and area in $\mathrm{mm} 2$. Screening of rhizobacterial isolates for formation of zinc solubilization zone

All the bacterial strains were screened for their ability to solubilize zinc in mineral salts agar medium was amended with $0.1 \%$ of either insoluble zinc oxide $(\mathrm{ZnO})$ or zinc phosphate $\mathrm{Zn}_{3}\left(\mathrm{PO}_{4}\right)_{2}$. The actively growing cultures $(5 \mu \mathrm{l})$ were spot inoculated onto the medium, incubated at $28^{\circ} \mathrm{C}$. Detection of zinc solubilization by different rhizobacterial isolates were based upon the ability of solubilization zone formation. The diameter of colony and clear zone around the colony was measured for calculating the solubilization efficiency in percent and area in $\mathrm{mm}^{2}$

\section{Results and Discussion}

Four (4) bacterial isolates selected which exhibiting clear zones around the colony for potassium solubilization and named as KSB-1 to KSB-4. KSB-2 isolated from cotton rhizosphere soil and KSB-1, KSB-4 from maize collected from College farm Rajendranagar PJTSAU. The isolate KSB-3 was isolated from rice rhizosphere soil collected from Student farm Rajendranagar PJTSAU (Table 2, Fig. 1 and Plate 1).

Eight (8) bacterial isolates were selected exhibiting clear zones around the colony for zinc solubilization and named as ZnSB-1 to ZnSB-8. The isolate ZnSB-1, ZnSB-3 isolated from cotton rhizosphere soil and ZnSB-5, ZnSB-6 from sorghum and ZnSB-2, ZnSB-4, ZnSB-8 from maize collected from College farm Rajendranagar PJTSAU. The isolate ZnSB-7 was isolated from rice rhizosphere soil collected from Student farm Rajendranagar PJTSAU. Two (2) fungal isolates ZnSF-1, ZnSF-2 were isolated from rice rhizosphere soil collected from Student farm Rajendranagar PJTSAU (Table 1, Fig. 2 and Plate 1).

Microbes play an important role in natural $\mathrm{K}$ cycles. Many studies have shown that soil contains a variety of KSB. These microbes decompose silicate minerals such as $\mathrm{K}$ feldspar and mica. They transform solid $\mathrm{K}$ in the soil into available $\mathrm{K}$ due to production of polysaccharide and organic acids that can be 
directly absorbed by plants, and they secrete active substances that promote plant growth. The use of KSB as a biological fertilizer is a hotspot in the study of agriculture and environmental conservation. Similarly, Archana et al., (2013) isolated thirty bacterial isolates capable of solubilizing potassium were obtained from the rhizosphere soil samples. Similarly, Prajapati and Modi (2012) isolated 14 bacterial isolates solubillizing potassium using feldspar (insoluble potassium) from the soil samples of ceramic industries. The zinc solubilizing bacterial isolates produce organic acid which help in solubilization of insoluble zinc compound. Similarly, Gandhi et al., (2014) isolated 240 zinc solubilizing bacterial strains from rhizosphere of rice. Based on the performance of bacterial strains, there were 15 isolates found to be potential zinc solubilizer.

\section{To screen pure isolates from different rhizosphere soils for potassium and zinc solubilization}

The isolated potassium and zinc solubilizing bacterial isolates were primarily screened for their ability of forming solubilizing zone by plate assay techniques. To determine solubilizing activity, $0.1 \mu \mathrm{l}$ of $48 \mathrm{~h}$ old test organism was placed at the centre of medium plate and incubated at room temperature. The mineral solubilizing activity was indicated as a clear zone around the colony and was quantified by measuring the width of the clear zone around the colony solubilization efficiency $(\%)$ and area $\left(\mathrm{mm}^{2}\right)$. Higher solubilizing zone producing colony was taken as an efficient isolate.

The isolated potassium solubilizing bacterial isolates (4) were inoculated in one Aleksandrov medium plate containing $0.2 \%$ potassium alumino silicate, as a source of insoluble potassium. After incubation at room temperature $\left(30 \pm 1^{\circ} \mathrm{C}\right)$ for 7 days the solubilization zone was measured. The solubilization zone is ranged from $160 \mathrm{~mm}$ to $85 \mathrm{~mm}$. The isolate KSB-2 showed maximum solubilization zone of $160 \mathrm{~mm}$ followed by KSB-1 with $110 \mathrm{~mm}$ and least solubilization zone was $85 \mathrm{~mm}$ for KSB-3. The solubilization efficiency (\%) ranges from 212.50 to $150 \%$ which is maximum for KSB-3 (212.50\%) and least for KSB-4 (150 $\%)$. The solubilization area $\left(\mathrm{mm}^{2}\right)$ was maximum for KSB-2 $\left(5024 \mathrm{~mm}^{2}\right)$ and least for KSB-4 $\left(706.50 \mathrm{~mm}^{2}\right)$ (Table 2 and Plate $2)$. All the isolates were solubilized potassium bearing minerals (potassium alumino silicate) by the action of organic acids and capsular polysaccharides.

The isolated zinc solubilizing bacterial isolates (8) were inoculated in on mineral salts agar medium containing 0.1 of either insoluble zinc oxide $(\mathrm{ZnO})$ and zinc phosphate $(\mathrm{ZnP})$, as a source of zinc. After incubation at room temperature $28 \pm 2{ }^{\circ} \mathrm{C}$ in incubator for 3-4 days the solubilization zone was measured (Figs. 2 and 3). The solubilization zone is ranged from $16 \mathrm{~mm}$ to 6 $\mathrm{mm}$ for $\mathrm{ZnO}$. The isolate $\mathrm{ZnSB}-3$ showed maximum solubilization zone of $16 \mathrm{~mm}$ followed by $\mathrm{ZnSB}-6$ with $11 \mathrm{~mm}$ and least solubilization zone was $6 \mathrm{~mm}$ for $\mathrm{ZnSB}-7$. The solubilization efficiency $(\%)$ ranges from 333.33 to $150 \%$ which was maximum for ZnSB-1 (333.33\%) and least for $\mathrm{ZnSB}-7$ $(150 \%)$. The solubilization area $\left(\mathrm{mm}^{2}\right)$ was maximum for $\mathrm{ZnSB}-3\left(63.58 \mathrm{~mm}^{2}\right)$ and least for $\mathrm{ZnSB}-7$ (3.14 $\left.\mathrm{mm}^{2}\right)$.

The solubilization zone for $\mathrm{ZnSF}$ is ranged from $85 \mathrm{~mm}$ to $34 \mathrm{~mm}$ for $\mathrm{ZnO}$. The isolate ZnSF-1 showed maximum solubilization zone of $85 \mathrm{~mm}$ followed by ZnSF-2 with 34 $\mathrm{mm}$ and least solubilization zone was $34 \mathrm{~mm}$ for $\mathrm{ZnSF}-2$. The solubilization efficiency (\%) ranges from $283.33 \%$ to $188.88 \%$ which is maximum for $\mathrm{ZnSB}-2$ (283.33\%) and least for $\mathrm{ZnSF}-1$ (188.88 \%). The solubilization 
area $\left(\mathrm{mm}^{2}\right)$ was maximum for $\mathrm{ZnSF}-1$ (1256 $\mathrm{mm}^{2}$ ) and least for ZnSF-2 (379.94 $\left.\mathrm{mm}^{2}\right)$ (Table 3 and Plate 2).

The isolated zinc solubilizing bacterial isolates (8) were inoculated in on mineral salts agar medium containing 0.1 of zinc phosphate $(\mathrm{ZnP})$, as a source of zinc. After incubation at room temperature $28 \pm 2^{\circ} \mathrm{C}$ in incubator for 3-4 days the solubilization zone was measured.

The solubilization zone is ranged from $6 \mathrm{~mm}$ to $25 \mathrm{~mm}$ for $\mathrm{ZnP}$. The isolate $\mathrm{ZnSB}-8$ showed maximum solubilization zone of 25 $\mathrm{mm}$ followed by ZnSB-6 with $11 \mathrm{~mm}$ and least solubilization zone is $6 \mathrm{~mm}$ for $\mathrm{ZnSB}-2$. The isolate $\mathrm{ZnSB}-1$, ZnSB-4, ZnSB-7 had not showed solubilization zone on $\mathrm{ZnP}$ amended medium. The solubilization efficiency (\%) ranges from $157.14 \%$ to 500 $\%$ which is maximum for $\mathrm{ZnSB}-8(500.0 \%)$ and least for $\mathrm{ZnS} 6(157.14 \%)$. The solubilization area $\left(\mathrm{mm}^{2}\right)$ was maximum for $\mathrm{ZnSB}-8$ (314 $\left.\mathrm{mm}^{2}\right)$ and least for $\mathrm{ZnSB}-3$ $\left(7.06 \mathrm{~mm}^{2}\right)$ (Table 4 and Plate 2$)$.
The ability of bacteria to solubilize K largely depends on the nature of the mineral compounds. The variability among the bacteria indicates the importance of exploration of different mineral potassium solubilizing bacteria and their solubilizing mechanisms. Bacterial isolates solubilized potassium through the production of exopolysaccharides around the colony. Similar results were obtained by Brindavathy and Gopalaswamy (2014) who screened 57 isolates for the bio-dissoluting potential for solubilization of silica and release of potassium for the formation of clearing zone around the colonies due to production of exopolysaccharides. Similar results were obtained by Parmar and Sindhu (2013) who screened One hundred and thirty seven bacterial isolates/strains for the potassium solubilization ability using spot test method on modified Aleksandrov medium, plates containing mica powder. They were found that out of 137 rhizobacterial isolates/strains tested, only 20 strains formed significant zone of $\mathrm{K}$ solubilization on mica powder containing medium plates.

Table.1 Details of places and crop plants used for isolation of potassium, zinc solubilizing bacteria and fungi

\begin{tabular}{|l|l|l|l|}
\hline S. No & Place & Crop & Isolates obtained \\
\hline 1 & College farm Rajendranagar PJTSAU & Cotton & KSB-2, ZnSB-1, ZnSB-3 \\
\hline 2 & College farm Rajendranagar PJTSAU & Maize & KSB-1, KSB-4, ZnSB-2, ZnSB-4, ZnSB-8 \\
\hline 3 & Student farm Rajendranagar PJTSAU & Rice & KSB-3, ZnSB-7, ZnSF-1, ZnSF-2 \\
\hline 4 & College farm Rajendranagar PJTSAU & Sorghum & ZnSB-5, ZnSB-6 \\
\hline
\end{tabular}

Table.2 Screening of bacterial isolates for potassium solubilization by plate assay

\begin{tabular}{|c|c|c|c|c|}
\hline \multirow[t]{3}{*}{ Isolate } & \multicolumn{4}{|c|}{ Potassium solubilization } \\
\hline & \multicolumn{2}{|c|}{ Zone diameter (mm) } & \multirow{2}{*}{ Solubilization efficiency $(\%)$} & \multirow[t]{2}{*}{ Area $\left(\mathbf{m m}^{2}\right)$} \\
\hline & $\begin{array}{c}\begin{array}{c}\text { Solubilization } \\
\text { zone }(\mathbf{m m})\end{array} \\
\end{array}$ & $\begin{array}{l}\text { Culture } \\
\text { diameter }\end{array}$ & & \\
\hline KSB-1 & 110.00 & 60.00 & 183.33 & 1962.50 \\
\hline KSB-2 & 160.00 & 80.00 & 200.00 & 5024.00 \\
\hline KSB-3 & 85.00 & 40.00 & 212.50 & 1589.62 \\
\hline KSB-4 & 90.00 & 60.00 & 150.00 & 706.50 \\
\hline C.D. & 2.484 & & & \\
\hline $\mathrm{SE}(\mathrm{m})$ & 0.750 & & & \\
\hline SE (d) & 1.061 & & & \\
\hline C.V. & 1.168 & & & \\
\hline
\end{tabular}

KSB - Potassium Solubilizing bacteria, SE - Standard Error

C.V. - Coefficient of Variance, DAI - Days after Incubation 
Table.3 Screening of different isolates for zinc solubilization $(0.1 \% \mathrm{ZnO})$ by plate assay at 3 days after incubation (3 DAI)

\begin{tabular}{|c|c|c|c|c|}
\hline \multirow[t]{3}{*}{ Isolate } & \multicolumn{4}{|c|}{ Zinc solubilization } \\
\hline & \multicolumn{2}{|c|}{ Zone diameter (mm) } & \multirow[t]{2}{*}{ Solubilization efficiency $(\%)$} & \multirow[t]{2}{*}{ Area $\left(\mathrm{mm}^{2}\right)$} \\
\hline & Solubilization zone & Culture diameter & & \\
\hline ZnSB-1 & 10 & 03 & 333.33 & 34.19 \\
\hline ZnSB-2 & 09 & 04 & 225.00 & 19.62 \\
\hline $\mathrm{ZnSB}-3$ & 16 & 07 & 228.57 & 63.58 \\
\hline $\mathrm{ZnSB}-4$ & 09 & 05 & 180.00 & 12.56 \\
\hline $\mathrm{ZnSB}-5$ & 08 & 04 & 200.00 & 12.56 \\
\hline ZnSB-6 & 11 & 06 & 183.33 & 19.62 \\
\hline ZnSB-7 & 06 & 04 & 150.00 & 3.14 \\
\hline ZnSB-8 & 07 & 04 & 175.00 & 7.06 \\
\hline $\mathrm{ZnSF}-1$ & 85 & 45 & 188.88 & 1256 \\
\hline $\mathrm{ZnSF}-2$ & 34 & 12 & 283.33 & 379.94 \\
\hline C.D. & 0.879 & & & \\
\hline $\mathrm{SE}(\mathrm{m})$ & 0.296 & & & \\
\hline $\mathrm{SE}(\mathrm{d})$ & 0.419 & & & \\
\hline C.V. & 2.629 & & & \\
\hline
\end{tabular}

Table.4 Screening of bacterial isolates for zinc solubilization with $0.1 \% \mathrm{Zn}_{3}\left(\mathrm{PO}_{4}\right)_{2}$ at 3 DAI

\begin{tabular}{|c|c|c|c|c|}
\hline \multirow[t]{3}{*}{ Isolate } & \multicolumn{4}{|c|}{ Zinc solubilization } \\
\hline & \multicolumn{2}{|c|}{ Zone diameter (mm) } & \multirow[t]{2}{*}{ Solubilization efficiency (\%) } & \multirow[t]{2}{*}{ Area $\left(\mathrm{mm}^{2}\right)$} \\
\hline & Solubilization zone & Culture diameter & & \\
\hline ZnSB-1 & 00 & 04 & - & - \\
\hline ZnSB-2 & 06 & 03 & 200.00 & 12.48 \\
\hline ZnSB-3 & 07 & 04 & 175.00 & 07.06 \\
\hline ZnSB-4 & 00 & 05 & - & - \\
\hline ZnSB-5 & 06 & 03 & 200.00 & 12.48 \\
\hline ZnSB-6 & 11 & 07 & 157.14 & 12.48 \\
\hline ZnSB-7 & 00 & 04 & - & - \\
\hline ZnSB-8 & 25 & 05 & 500.00 & 314.00 \\
\hline C.D. & 0.668 & & & \\
\hline $\mathrm{SE}(\mathrm{m})$ & 0.221 & & & \\
\hline SE (d) & 0.312 & & & \\
\hline C.V. & 5.563 & & & \\
\hline
\end{tabular}

Fig.1 Screening of KSB bacterial isolates for potassium solubilization by plate assay

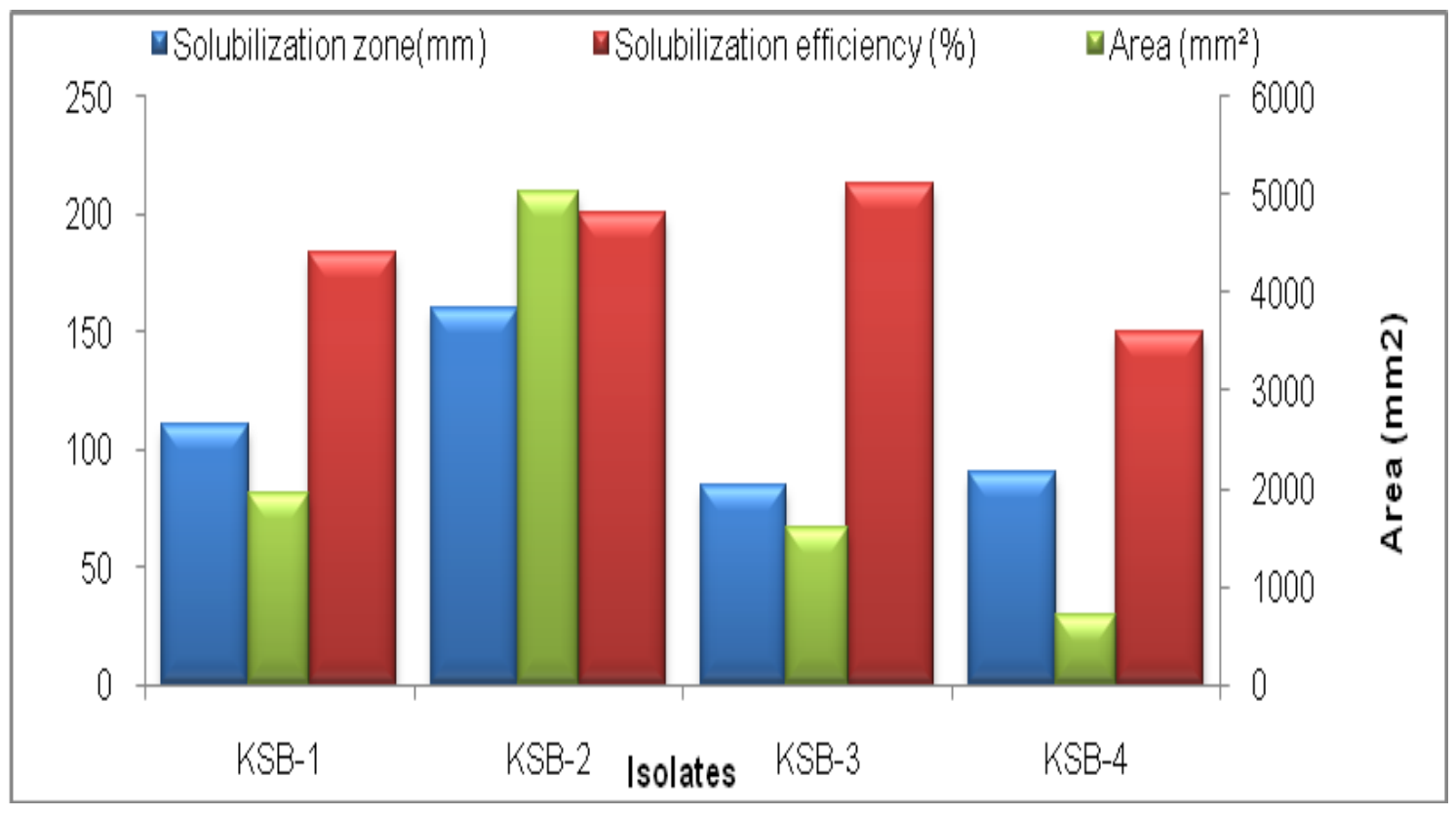


Fig.2 Screening of $\mathrm{ZnSB}$ and $\mathrm{ZnSF}$ bacterial isolates for zinc oxide solubilization by plate assay

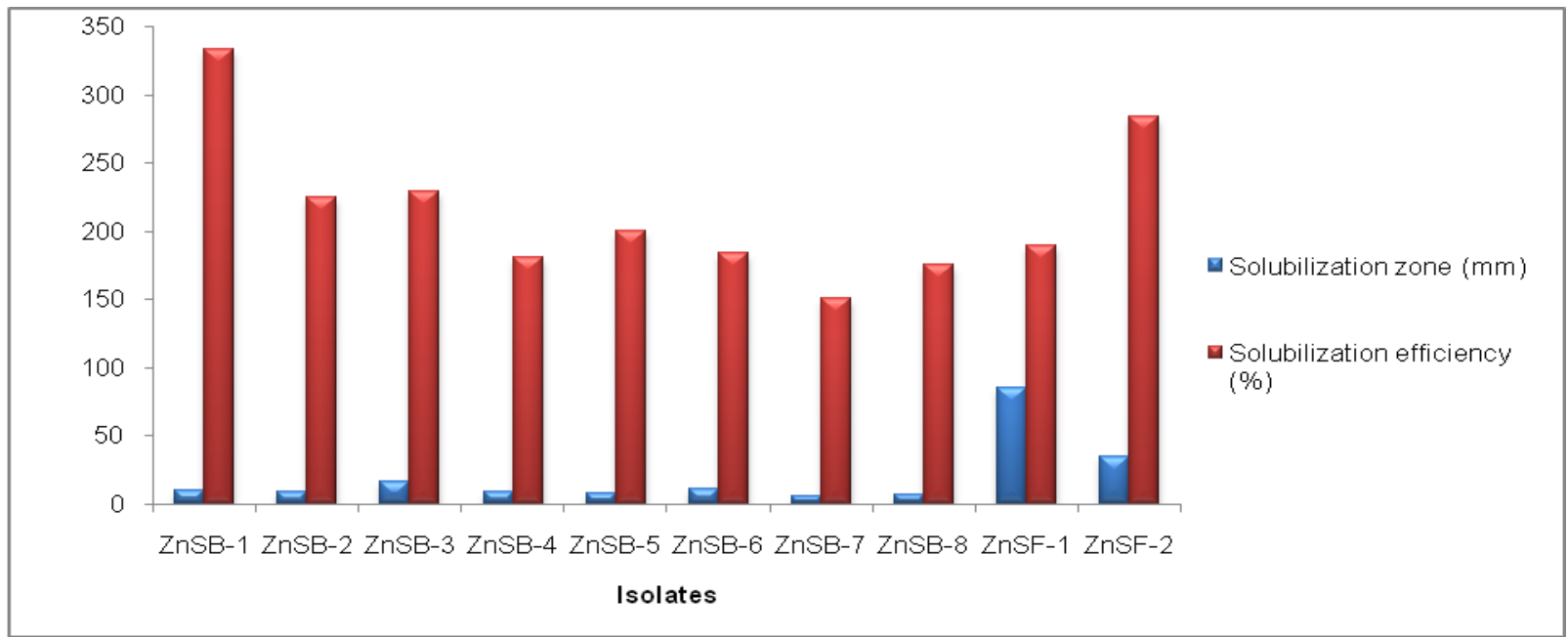

ZnSB - Zinc Solubilizing bacteria, ZnSF - Zinc Solubilizing Fungi

Fig.3 Screening of ZnSB bacterial isolates for zinc phosphate solubilization by plate assay

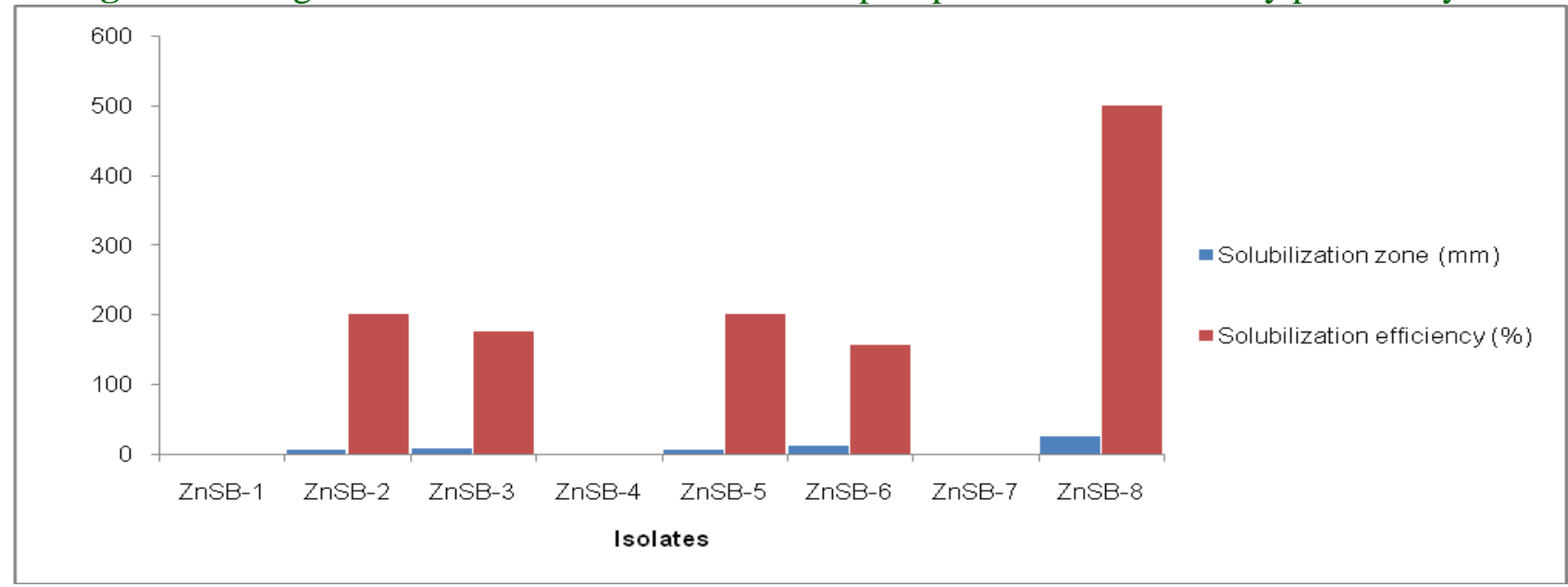

Plate.1 Study of different isolates of potassium and zinc solubilization

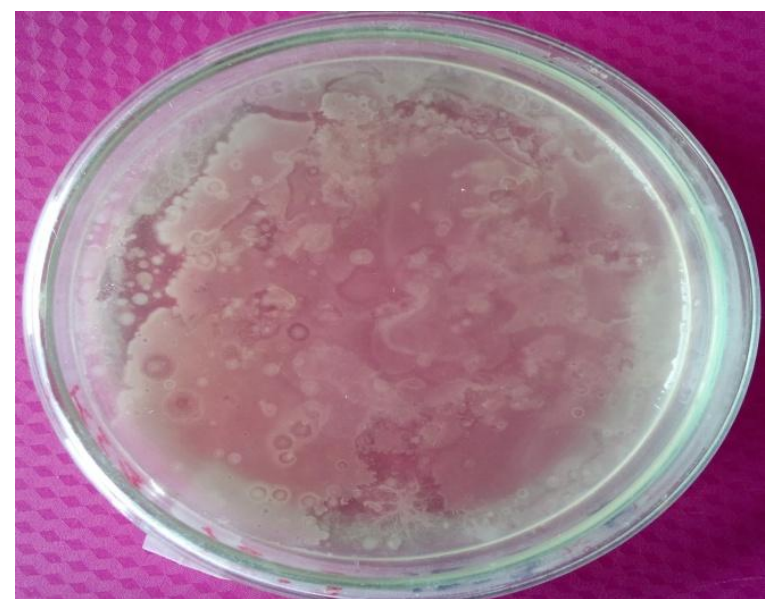

a) Potassium solubilization 


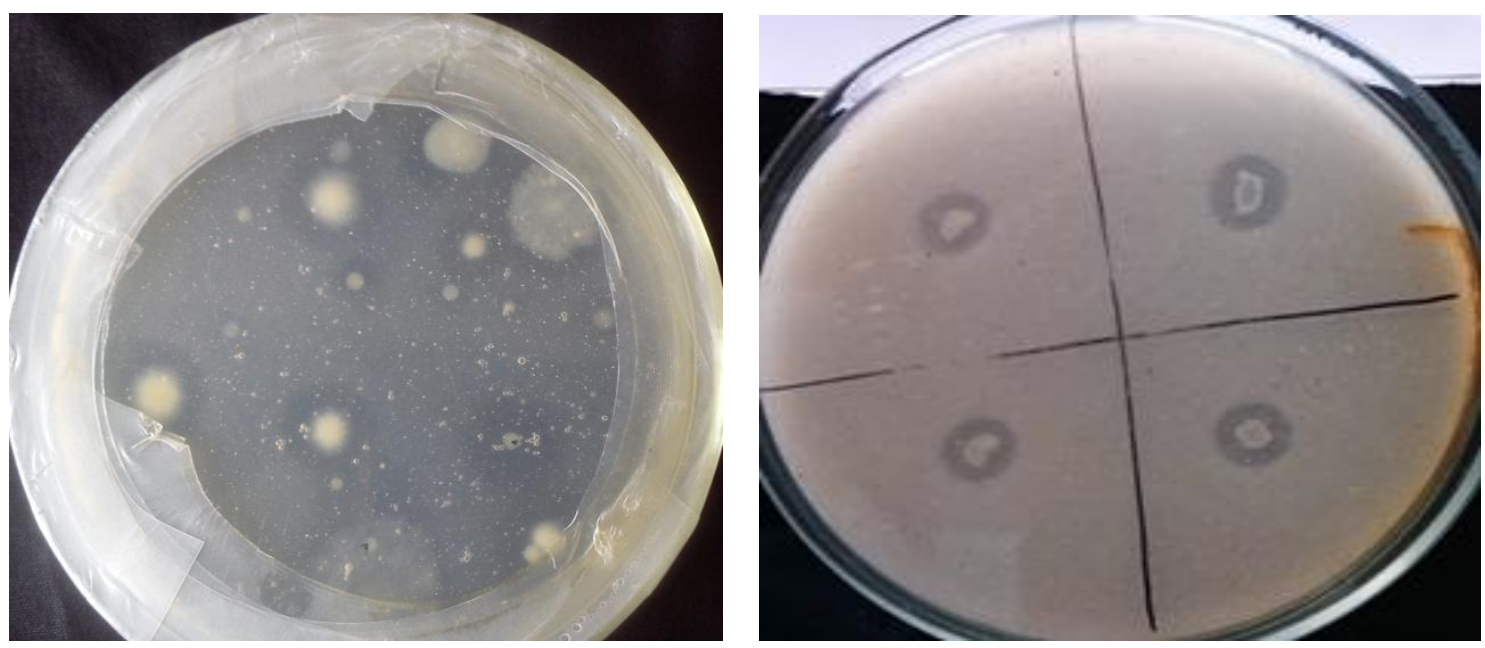

b) Zinc solubilization by bacteria

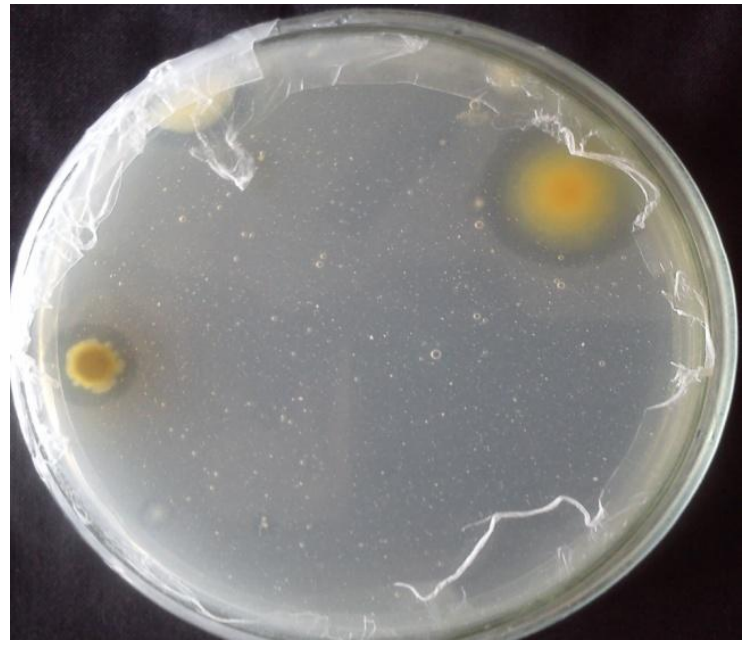

b) Zinc solubilization by fungi

Plate.2 Different isolates screened for potassium and zinc solubilization with insoluble source

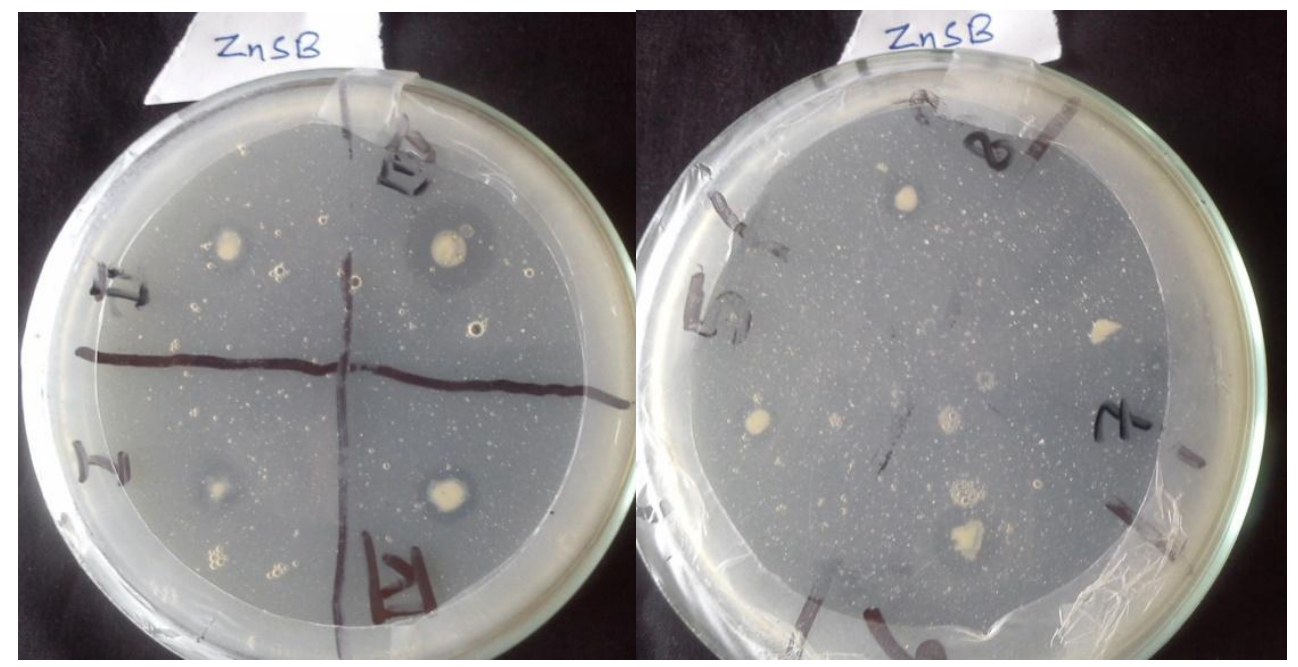

a) Zinc oxide (ZnO) solubilization by bacteria 


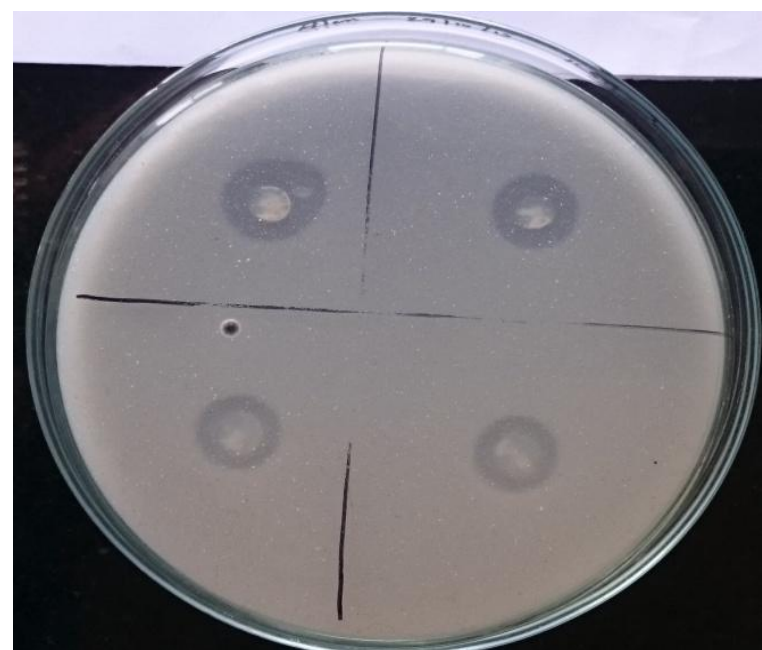

b) Potassium solubilization

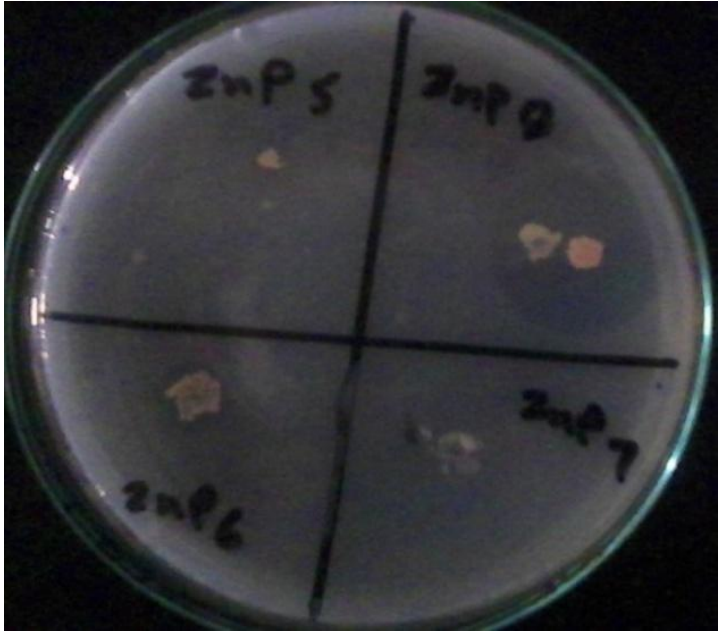

c) Zinc phosphate (ZnP) solubilization

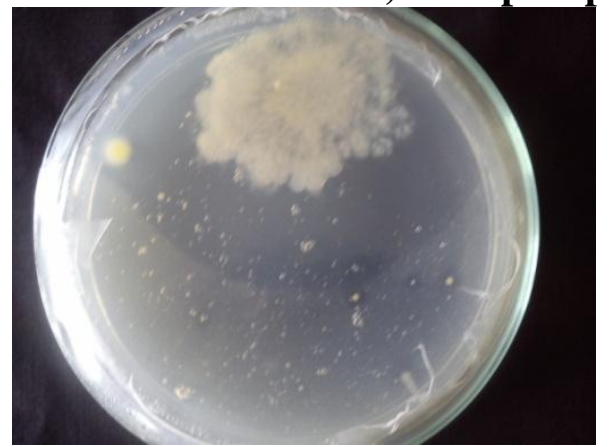

d) Zinc phosphate (ZnP) solubilization by fungi

Solubilization of zinc phosphate occurred by both an increase in the $\mathrm{H}+$ concentration of the medium, probably a consequence of ammonia assimilation, and the production of gluconic acid. Although under some conditions gluconic acid was purportedly able to solubilize metals by the formation of chelates, no evidence of zinc chelation was obtained in our experiments. Similar results were obtained by Zinc phosphate solubilization by a strain of Pseudomonas fluorescens was investigated by Simine et al., They identified that gluconic acids produced in culture medium helped in solubilization of zinc salts.

Isolates gives a clue that the solubilization could be due to production of organic acids. The more production of organic acid improves the available zinc in the culture broth. Similar observations noticed by Desai et al., (2012) reported that higher availability of $\mathrm{Zn}$ is directly proportional to acidic $\mathrm{pH}$ of the culture broth.

In conclusion, Four (4) potassium solubilizing bacteria was isolated and named as KSB-1 to KSB-4. KSB-2 isolated from cotton rhizosphere soil and KSB-1, KSB-4 from maize collected from college farm Rajendranagar PJTSAU. The isolate KSB-3 was isolated from rice rhizosphere soil collected from student farm Rajendranagar PJTSAU.

Eight (8) zinc solubilizing bacteria was isolated and named as $\mathrm{ZnSB}-1$ to $\mathrm{ZnSB}-8$. The isolate ZnSB-1, ZnSB-3 isolated from cotton rhizosphere soil and ZnSB-5, ZnSB-6 from sorghum and ZnSB-2, ZnSB-4, ZnSB-8 from maize collected from college farm Rajendranagar PJTSAU. The isolate ZnSB-7 
was isolated from rice rhizosphere soil collected from student farm Rajendranagar PJTSAU. Two (2) fungal isolates ZnSF-1, ZnSF-2 were isolated from rice rhizosphere soil collected from student farm Rajendranagar PJTSAU.

The isolated potassium solubilizing bacterial isolates were screened for solubilization of insoluble potassium. The solubilization zone is ranged from $160 \mathrm{~mm}$ to $85 \mathrm{~mm}$. The isolate KSB-2 showed maximum solubilized zone of $160 \mathrm{~mm}$ followed by KSB-1 with $110 \mathrm{~mm}$ and least solubilization zone was $85 \mathrm{~mm}$ for KSB-3. The solubilization efficiency (\%) ranges from $212.50 \%$ to $150 \%$ which was maximum for KSB-3 (212.50 \%) and least for KSB-4 (150\%). The solubilization area $\left(\mathrm{mm}^{2}\right)$ was maximum for KSB-2 $\left(5024 \mathrm{~mm}^{2}\right)$ and least for KSB-4 $\left(706.50 \mathrm{~mm}^{2}\right)$. All the isolates could solubilized potassium bearing minerals (potassium alumino silicate) by the prodction of organic acid and capsular polysaccharides.

The isolated zinc solubilizing bacterial isolates were screened for solubilization of insoluble zinc oxide $(\mathrm{ZnO})$ as a source of zinc. The solubilization zone is ranged from $16 \mathrm{~mm}$ to $6 \mathrm{~mm}$ for $\mathrm{ZnO}$. The isolate $\mathrm{ZnSB}-3$ showed maximum solubilization zone of 16 $\mathrm{mm}$ followed by ZnSB-6 with $11 \mathrm{~mm}$ and least solubilization zone was $6 \mathrm{~mm}$ for $\mathrm{ZnSB}-$ 7. The solubilization efficiency $(\%)$ ranges from $333.33 \%$ to $150 \%$ which was maximum for $\mathrm{ZnSB}-1$ (333.33 \%) and least for $\mathrm{ZnSB}-7$ (150\%). The solubilization area $\left(\mathrm{mm}^{2}\right)$ was maximum for $\mathrm{ZnSB}-3$ (63.58 $\left.\mathrm{mm}^{2}\right)$ and least for $\mathrm{ZnSB}-7\left(3.14 \mathrm{~mm}^{2}\right)$. The solubilization zone for $\mathrm{ZnSF}$ is ranged from $85 \mathrm{~mm}$ to $34 \mathrm{~mm}$ for $\mathrm{ZnO}$. The isolate $\mathrm{ZnSF}-$ 1 was recorded maximum solubilization zone of $85 \mathrm{~mm}$ followed by ZnSF-2 with $34 \mathrm{~mm}$ and least solubilization zone was $34 \mathrm{~mm}$ for $\mathrm{ZnSF}-2$. The solubilization efficiency (\%) ranges from $283.33 \%$ to $188.88 \%$ which was maximum for $\mathrm{ZnSB}-2$ (283.33\%) and least for $\mathrm{ZnSF}-1$ (188.88\%). The solubilization area $\left(\mathrm{mm}^{2}\right)$ was maximum for $\mathrm{ZnSF}-1$ (1256 $\mathrm{mm}^{2}$ ) and least for $\mathrm{ZnSF}-2$ (379.94 $\left.\mathrm{mm}^{2}\right)$.

The isolated zinc solubilizing bacterial isolates were screened for solubilization of zinc phosphate. The solubilization zone is ranged from $6 \mathrm{~mm}$ to $25 \mathrm{~mm}$ for $\mathrm{ZnP}$. The isolate $\mathrm{ZnSB}-8$ showed maximum solubilization zone of $25 \mathrm{~mm}$ followed by ZnSB-6 with $11 \mathrm{~mm}$ and least solubilization zone was $6 \mathrm{~mm}$ for $\mathrm{ZnSB}-2$. The isolate ZnSB-1, ZnSB-4, ZnSB-7 do not showed any solubilization zone on Zinc phosphate amended medium. The solubilization efficiency (\%) ranges from $157.14 \%$ to 500.0 $\%$ which was maximum for $\mathrm{ZnSB}-8$ (500.0 $\%)$ and least for ZnSB-6 (157.14 \%). The solubilization area $\left(\mathrm{mm}^{2}\right)$ was maximum for ZnSB-8 (314 $\left.\mathrm{mm}^{2}\right)$ and least for $\mathrm{ZnSB}-3$ $\left(7.06 \mathrm{~mm}^{2}\right)$.

The bacterial isolate KSB-2 solubilized more potassium, ZnSB-8 solubilized more zinc phosphate and ZnSF-1 solubilized more zinc oxide in both plate assay. The ZnSB-3 solubilized more zinc oxide in plate assay. So, we can use these isolates as a good solubilizer for sustainable solution to improve plant nutrition and production.

\section{References}

Abbas, Z.P., Saleh, R.N., Asadi, R.H., Khavazi, K., Soltani, A., Shoary, N.A.R and Miransari, M. 2010. Plant growth-promoting activities of fluorescent Pseudomonads isolated from the Iranian soils. Acta Physiologiae Plantarum. 32: 281-288.

Badar, M.A. 2006. Efficiency of K- feldspar combined with organic material and silicate dissolving bacteria on tomato yield. Journal of Applied Sciences Research. 2(12): 1191-1198. 
Ullaman, W.J., Kirchman, D.L. and Welch, W.A. 1996. Laboratory evidence by microbially mediated silicate mineral dissolution in nature. Chemical Geology. 132: 11-17.

Saravanan, V.S., Madhaiyan, $M$ and Thangaraju, M. 2007. Solubilization of zinc compounds by the diazotrophic, plant growth promoting bacterium Gluconacetobacter diazotrophicus. Chemosphere 66, 1794-1798.

Gadd, G. M. 2007. Geomycology: Biogeochemical transformations of rocks, minerals, metals and radionuclides by fungi, bioweathering and bioremediation. Mycological Research. 111: 3-49.

Aneja, K.R. 2001. Experiments in Microbiology, Plant Pathology and Tissue culture. Viswaprakasham, New Delhi. 471.

Cappuccino, J.G and Sherman, N. 1992. “ Microbiology: A laboratory manual”. The Benjamin/Comings Publishing Company, Inc. California.

Nene and Thapliyal. 1993. Fungicides in Plant Disease Control, Oxford and IBH Publishing House, New Delhi. 163.

Archana, D.S., Nandish, M.S., Savalagi, V.P and Alagawadi, A.R. 2012. Screening of potassium solubilizing bacteria (KSB) for plant growth promotional activity. Bioinfolet. 9(4A): 627-630.

Gandhi, A., Muralidharan, G., Sudhakar, E and Murugan, A. 2014. International Journal of Recent Scientific Research. 5: pp. 2201-2204.

Prajapati, K.B and Modi, H.A. 2012. Isolation and characterization of potassium solubilizing bacteria from ceramic industry soil. Journal of Microbiology. (2-3): pp. 8-14.

Brindavathy, R And Gopalaswamy, G. 2014. Isolation and characterization of biodissoluting bacterium from different regions of Tamil Nadu. Trends in Biosciences. 7(22): 3651-3659.

Parmar, P and Sindhu, S.S. 2013. Potassium solubilization by rhizosphere bacteria: influence of nutritional and environmental conditions. Journal of Microbiology Research. 3(1): 25-31.

Desai, S., Kumar, P.G., Sultana, U., Pinisetty, S., Ahmed, M. H. S. K., Amalraj, L. D. E and Reddy, G. 2012. Potential microbial candidate strains for management of nutrient requirements of crops. African Journal of Microbiology Research. 6: 3924-3931.

\section{How to cite this article:}

Bhagwan Singh Dhaked, S. Triveni, R. Subhash Reddy and Padmaja G. 2017. Isolation and Screening of Potassium and Zinc Solubilizing Bacteria from Different Rhizosphere Soil. Int.J.Curr.Microbiol.App.Sci. 6(8): 1271-1281. doi: https://doi.org/10.20546/ijcmas.2017.608.154 